\title{
Putting People First in Practice: Indonesia and the Kecamatan Development Program
}

\author{
Scott Guggenheim
}

Michael Cernea's key insight was that the core concepts of sociology and anthropology - social organization, culture, participation, and symbolic constructioncould improve the quality and effectiveness of development. His key achievement was in the fact that he and the people he inspired were able to bridge the gap between analyst and practitioner to show that these anthropological and sociological concepts really could make a difference in how development affected the poor. In this article, I'll do my best to use describe my own journey from naïve graduate student to World Bank team leader for the Kecamatan Development Program, one of the world's earliest and largest community development programs.

\section{Discovering Development}

I came to know Michael Cernea after finishing a graduate program that had been heavily focused on Latin American anthropology. In fact, I ended up doing my Ph.D. on the political economy of agrarian change in the northern Philippines because I'd planned to return to Mexico and this would be my last chance to get a US funding organization to finance comparative research. During the course of my fieldwork, I now and then found myself spending several days accompanying wedding parties that were bringing Ibanag brides from the lowland villages where I was working on long hikes up to the communities of the Kalinga highlands. Several of these Kalinga groups lived alongside the Chico River. There, the Marcos government, supported by World Bank financing and a German engineering firm hired to handle the technical design, was just starting on the construction of the first of four large hydroelectric dams. The Kalinga villages had already rejected the fairly paltry

\footnotetext{
S. Guggenheim $(\bowtie)$

Edmund Walsh School, Georgetown University, Washington, DC, USA 
compensation they were being offered. They argued that both that these lands were historically and culturally sacred. And, contradicting the national modernizers who were accusing them and their NGO allies of wanting to stay preserved in an outdoor museum, their leaders often said that while they had no objection to joining "modern" society, they had no plans to join it at the bottom.

The government's reaction was ferocious. Aside from the Philippine Constabulary forces already assigned to the province, the 60th Philippine Constabulary Brigade, the 51st Philippine Constabulary Brigade, and the 44th Philippine Army Brigade were brought in to suppress opposition to the dam project. Villages were bombed and then burned. This achieved little. The largely urban originated New People's Army began making its presence known, fortified by a rising level of local support, which of course then brought more military to the north. As the conflict worsened, I visited the World Bank's office in Manila to see what they knew about the unfolding mayhem, but they had no records and it seemed that nobody from their team had ever visited the highland communities to check for himself or herself what was going on. But I had a thesis to write, so I returned to Tuguegarao, saddened, disgusted, and angry, but also pretty irked by my powerlessness. Years later, though, the entire scheme was cancelled. ${ }^{1}$

Like most graduate students, I had sufficient funding to do my fieldwork, barely, but when the time came to turn the notebooks into a dissertation, my choices were pretty grim. After spending a painful year scraping by doing adjunct teaching in a place where I spent more money getting to the college than the college was paying me for the course, I called pretty much everyone I knew to see if they could find a job that would at least fund my write-up.

My third call was to a very smart classmate who had been working at the World Bank, and was obviously fed up with the place. "You want it?" she asked, "Be my guest!" She arranged for an interview with her boss, a disheveled and slightly scary Romanian sociologist who grilled me about Robert Chambers, the Anand dairy cooperative in India, and my views on the potential of social forestry, none of which I had ever heard of before. Fortunately, we also managed to chat a bit about Eric Wolf and Sidney Mintz, both of whom I knew because they were my thesis advisers. Over a wrap-up lunch in the lush World Bank cafeteria, he asked about my views on whether Henry Kissinger and the Nixon administration might have had a point given what ensued. Realizing that I'd completely blown the interview, I figured why not just say what I really thought, temple of expansive capitalism though this was.

After Michael hired me, we began a small project together to see if the Chico River projects that I'd seen in the Philippines were an aberrant case of a military dictator bypassing development's ground rules, or whether there were more examples of Bank-financed projects ignoring the Bank's own social and environmental policy requirements. Just 2 years earlier, Michael had somehow recently managed to

\footnotetext{
${ }^{1}$ Though, proving Michael's dictum that there is no such thing as a dead project, in 2019 it was again revived, and as of this writing in 2020, it has again been suspended for again lacking the informed consent of the indigenous population.
} 
turn into compulsory if frequently ignored planning requirements for all large projects. Well, needless to say, wherever there was information-and in most cases there wasn' $\mathrm{t}$ - we did not find a very complimentary story. In fact, the main factor governing whether the Bank even raised a peep over poor people's forced displacement and subsequent misery seemed to be whether the individual project officer was a nice guy or, in a few cases, a nice woman. Most simply thought this wasn't the Bank's business, and some, unwittingly but openly repeating Josef Stalin, would say in that hard-eyed, flinty, willing-to-make-the-tough calls sort of self-confident, dismissive way, "well, you can't make an omelet without breaking some eggs."

Having by then scraped together enough money to finish my thesis, I happily left the World Bank to take up a post-doc with the International Fertilizer Development Centre in Cali, Colombia, South America, where I spent the next 3 years doing farming systems research across the northern Andes, still planning to return to Mexico.

Fate had a different plan for me. One day, I picked up the phone. It was someone from the World Bank, asking whether I could join them on an environmental assessment of the impacts that a large dam on Somalia's Baardhere River would have on the population of endangered Nile crocodiles. The problem was not the impact that a large dam would have on the endangered Nile crocodiles, but that turned out that while the Nile crocodile population was probably not all that threatened, there were no plans for resettling the 140,000 local farmers and refugees settled along the river banks who hadn't been counted in the feasibility assessments. Soon after, civil war broke out and that Baardheere River dam was never built.

But I was hooked.

Rejoining Michael back in Washington DC, my first job was mostly helping Michael finish the editing for the chapters that eventually became Putting People First, 2nd edition. But that was just the platform for the much more exciting job of helping Michael work through a strategy for getting the World Bank's resettlement policy turned into actual actions, not just largely ignored lip service. One day, Michael casually asked me to join a supervision mission to a large project in western India, one that he said was the touchstone for the seriousness of the human issues at stake and the high-stakes that were involved when so much power and money were in play. I vaguely remembered reading the Narmada River Sardar Sarovar Dam and Irrigation Project report from my time doing that first resettlement review with Michael, but since then, Narmada had become an international cause celebre.

The first big surprise after I got to western India was how little of what had sounded like very precise planning in the Bank's documents was anywhere to be found in the actual project. However, what was actually there was a mass civic mobilization opposed to the project, a dug-in government and Bank project team, and a whole range of international environmental and activist groups who saw Narmada as a test case for attacking World Bank style big development.

Philippines, Somalia, India. ....there was a trend developing. We dived, headfirst, into a global effort to find out what was happening to the people being displaced by 
some 200 World Bank projects that were causing resettlement. The Bank's guidelines, we thought, were clear enough. But were they being followed? And what happened to those people? Did anyone know?

Four years later, in late 1994, Michael and I were finishing off the Bankwide Review of Involuntary Resettlement. We were exhausted. Retrospectively, it's hard to convey how emotionally difficult it was to carry out a review that needed to translate some pretty horrific violations of the basic rights of very poor people into a language that could be heard by and convince powerful, articulate people who were intellectually vested in the basic "big push" development framework. Many of them were also ensnared in strong institutional and even personal interests, such as lending pipelines to a big borrower, and individual career promotions. Sparks flew in almost every meeting. While after finishing that report I just wanted to get out of Washington and possibly even the Bank, the controversy seemed to energize Michael even more, and the high-level follow-up that ensued is entirely to his credit.

Indonesia was the first World Bank country office that asked Michael for help in cleaning up their resettlement portfolio. Faced with an increasingly uncomfortable public image, the Bank program in Indonesia had recently formed a special unit to handle social and environmental issues. But one project, the Kedung Ombo Dam and Irrigation project, was just too complex to be handled locally. Singled out by the global activists as one of the five World Bank "global disasters," Kedung Ombo was yet another large Bank-financed irrigation dam that had closed its gates to start filling the reservoir before the resettlement was done. In fact, a fairly large fraction of its 35,000 villagers was still living in the flood zone. Many were people who had accepted the government's "transmigration" offer but had returned when they found that the transmigration sites were unlivable, lacking virtually all of the promised amenities and often surrounded by sullen and hostile people whose lands had been taken away by force. Nearly all of them were poor people whose livelihood problems were exacerbated by the government's belief that many of them had been supporters of the Indonesian communist party at the time when the 1965 coup and massacres of as many as a million people took place, 30 years previously. They were still being punished by the New Order administration, the quasi-military government led by general Suharto that had taken place after the coup. Official lies and cover-ups were everywhere.

In the end, we achieved very little by way of remedial action, despite a few pilots and a lot of pressure, both from the Bank itself and from the international activist community. What we tried was just too late, and as the East Asia financial crisis began spreading across Indonesia, the entire New Order administration's development apparatus had started to crumble, which pretty much ended anyone's interest in pursuing the problem. But that experience gave me a very painful crash course in Michael's first lesson: that the challenge for a development anthropologist is not just to understand local social structure, social organization, or culture. That is, as always, key. But the other half of that story is to learn to use the language of the Bank, to know how its rules, tools, and ways to frame the world in a way that lets the Bank act on it. It really didn't take more than one trip to Kedung Ombo to see what a mess the resettlement was. By that point, only a few holdouts claimed otherwise. But 
now that everyone agreed that it was awful and something must be done, what was that "something" and who should be doing it? I quickly found out that other than bleating about how horrible it all was, I was not really able to translate that knowledge into the concepts, vocabulary, and instruments that states and development agencies use to think with. My real education was just starting.

\section{Ethnography for Development: The Local Institutions Studies}

Before leaving Washington for Jakarta, I'd spent some time working with Gloria Davis (see chapter by Gloria Davis), an anthropologist who not only had become the Bank's first Director for Social Development but had also done her Ph.D. and professional work in Indonesia. Gloria had put together a global study team guided by the Harvard political scientist Robert Putnam, whose task was to assess whether we could measure and perhaps one day use Putnam's concept of social capital for development. ${ }^{2}$ The unique feature of the study was not so much the idea that communities can act collectively, but that we could contrast the way that communities naturally carry out collective action with what happens when Bank financed development projects rely on government staff to control local development decisions.

The answers were not quite as simple as "community good/government bad". I've described elsewhere the results from those local institutions' studies, ${ }^{3}$ but I can summarize them briefly here. First, they did show that indigenous community institutions covered as diverse a range of activities as development agency created user groups did; they were in general more participatory and more inclusive; and they operated under both formal and informal rules that gave mechanisms for addressing problems and resolving complaints. They were also multi-functional and were sustained over time, much like the "corporate" community structures that my adviser Eric Wolf had described 40 years earlier. But unlike Wolf's closed corporate peasant communities, Indonesian villages were well networked with the external world, particularly, in many places, through market centers and traditional small principalities that under the Dutch had been given the juridical status of "kecamatans," subdistricts composed of anywhere from 6 to 40 or more villages. However, our potted ethnographies also showed that many communities lacked

\footnotetext{
${ }^{2}$ Robert D. Putnam, Making Democracy Work, Princeton, New Jersey: 1993.

${ }^{3}$ See Scott Guggenheim, "Crisis and Contradictions" in M. Woolcock, A. Bebbington, and S. Guggenheim, Eds, Understanding Social Capital Debates at The World Bank. Washington, DC.; also Kamala Chandrakirana et. al, The Local Institutions Study, unpublished World Bank report, 1999, but summarized in http://siteresources.worldbank.org/INTSOCIALCAPITAL/ Resources/Local-Level-Institutions-Working-Paper-Series/LLI-WPS-2.pdf
} 
technical skills, that many of them were experiencing a leadership crisis, and that they were often defrauded by urban or market players.

But the most interesting aspect of all this wasn't necessarily these findings about social capital in Indonesian villages. It was what was going on in the national government and how that was about to transform the relationship that these communities had with the state.

Indonesia's development model had been very textbook development. Largescale technocratic service delivery ministries that built thousands of roads, schools, clinics, and so on complemented good macro-economic management and lots of foreign investment. Development was still largely low skilled, and most people lived from farming, But an economy traditionally dependent on hydrocarbons and forestry exports was already diversifying into light manufacturing and services. Poverty rates, though still dire, were nothing like they were when the Dutch left Indonesia in 1949 .

The Bank was very vested in this model. Some people grumbled about the lack of political liberty and we, who spent a lot of time in the field, were often appalled by the levels of corruption and authoritarianism that were not so visible in official reports. Even so, most people were expecting that the next 20 years would be more or less like the previous two decades, with the economy continuing to grow, poverty rates slowly declining, and President Suharto anointing a successor from his inner circle.

Boy, were we wrong.

Indonesia's Kecamatan Development Program When Indonesia's economic and then its political crisis first broke in 1997, we were just putting the finishing touches on a small pilot program that tried to build on the social capital studies by seeing if we could switch from development project created community groups to just letting communities use the groups they already had. This was turning out to be harder to do than I had anticipated. It was great to argue that villagers should be allowed to plan and manage their own development projects, but you can't just hand out bags of public money to villagers and say "go for it," or at least you couldn't legally do that back then. Issues of who gets the money, what can it be spent on, who is liable for it, how is it accounted for, and what happens when things go wrong were just the opening round of questions.

I actually never could figure out the answers to most of these questions. But I didn't have to, either. Once we had the evidence to show that community organizations could carry out small-scale projects if we could shed much of the typical project superstructure, which had too many steps and was too complicated for managing community level programs, it turned out that the Bank and also the Indonesian government had a whole tier of specialists who were just dying to help make an experiment like this work. We spent the next 5 months working through the ethnographic data on how people organize, the government's legal and financial structure for how to move money down to whatever community organizations would end up doing the work, and what kind of reporting flows government auditors and others would require to prove that the money had been well spent. 
Our pilot was just getting underway when, on May 21, 1998, President Suharto resigned. The economic crisis had already started, but after Suharto's fall, the extent to which the New Order officials had looted the banking system was revealed. That year, GDP shrank by $13.5 \%$, taking much of the middle class and all of Indonesia's development apparatus with it. Desperate for ways to get money to the communities that were being directly and indirectly hit by the crisis, both the government and the Bank turned to our little 6 kecamatan (subdistrict) pilot and asked whether we could scale it up, no matter how unprepared we thought we might be. I generally believe that the value of a development pilot is from the analytical and practical work that goes into its design rather than the analysis of the results, which usually takes too long to be useful. So, we assembled a small task force that would work on the design, carry out some fast and dirty surveys to monitor the unfolding crisis, ${ }^{4}$ and help the government begin recruiting field staff so that they could launch the emergency program.

The basic architecture of the KDP (Kecamatan Development Project) project that emerged from all of this mix consisted of block grants provided directly by the central government to kecamatan (subdistrict) councils. They could use the grants to fund development plans that had been prepared through a 4-6 month long participatory planning process. Planning began in hamlets. Community plans were then consolidated, presented, and reviewed in village-wide decision meetings before being submitted to the kecamatan council, where the proposals from a number of villages were presented for a public discussion. KDP rules required that any village group submitting a proposal must send a delegation of at least six community representatives, including the village head and at least three women, to the kecamatan meetings where villagers would collectively decide which proposals would be funded. Each village could submit up to two proposals to the kecamatan council. This always led to proposals for more projects than could be funded with the available resources, so the villagers had to negotiate among themselves which proposals were the most worthy. Once the kecamatan forum agreed on which proposals merited funding, nobody further up the system could modify them. Funds were released from the provincial branch of the national treasury directly to a bank account held in the name of all of the villagers. Villagers then ran the show.

In many senses, much of KDP's architecture was built out of spare parts: the funding system was swiped from one of Suharto's top-down transfer programs for "left behind" communities; the engineering came from another World Bank village roads program; and some of the planning ideas came from the UNICEF inspired participatory water and sanitation projects that were popular at the time (and which let villages plan for whatever they wanted as long as it was water).

But other parts came from the sociological fieldwork that the local institutions team had carried out. Whereas most of the operational bits that we borrowed from other projects were concerned with how to adapt development rules to community

\footnotetext{
${ }^{4}$ Sudarno Sumarto, Anna Wetterberg, Lant Pritchett, "The Social Impact of the Crisis in Indonesia: Results from a Nationwide Kecamatan Survey,” World Bank, 1999.
} 
level work, what the studies were really concerned with was how to build in better processes for providing voice, agency, and representation in the ways that communities engaged with development projects. From a development project standpoint, some of KDP's most innovative ideas involved things like dramatically simplifying contract formats, or disbursing against village plans rather than requiring paid receipts for bags of cement or contractor's reports. From an anthropological perspective, the most innovative parts were actions such as locating planning within the hamlet (dusun) but decision-making in the sub-district (kecamatan), the historical and symbolic meeting point. Similarly, while traditional culture in most of Indonesia had defined public roles for women, in pretty much no part of Indonesia was there a decision-making role for women outside of the official "homemaker's" organization ("PKK") when it came to deciding on government projects or spending development funds. How malleable was local culture going to be on giving women a voice in how KDP funds would get spent and accounted for?

More elaborately, our fieldwork had uncovered the ways in which the transactional structures of government projects provided both monopoly control over information flows as well as too much official discretion over community decision-making, big parts of what was needed to explain why there was so much corruption and distrust in so many of the current projects. As the team unpicked the ethnographic data, we worked hard to turn it into design steps that would start to break the monopolies and eliminate most of the discretion, producing the kinds of sociologically informed designs that Michael was recommending to Bank operations as a whole.

KDP then and Now From its operational launch in 48 villages in 1998, KDP went through a continual scale-up, reaching some 2000 villages by 2002; and then 6000 by 2006 , when it was renamed as Indonesia's National Program for Community Empowerment. From there, it scaled up very rapidly, reaching 60,000 villages by 2011 , and all of Indonesia's 75,000 villages by 2017, by which time the government had enshrined it in a national village law that embedded the program in the national budget. By 2019 , the program was disbursing some US $\$ 8.8$ billion/year, nearly $6 \%$ of Indonesia's GDP, a sum far beyond anything a development agency like the World Bank could ever have supported by itself.

But KDPs influence was not just through the 20-year scale-up. Once the dam had been broken, the government realized that shifting from a project delivery mode to community partnerships gave them a new template for a wide range of activities. The government's globally noteworthy program for its recovery from the devastating 2004 Aceh/Nias tsunami was built on this same community development platform, one of whose foundational features was to get displaced people out of the camps and back working on their community's reconstruction within weeks of the disaster. The government has now made this model of community-based recovery a mainstay of its disaster-handling program. Colleagues from education and health also began looking at ways to use the community partnership model to increase coverage and move past some of the highly centralized models of the New Order era. And other countries, such as the Philippines, Myanmar, Afghanistan and even Liberia claim to 
have borrowed and adapted elements of the program —including the admonitions that they needed to do their own social analysis, experimentation, and adaptation, not just replicate Indonesia.

Not all has been rosy, however. Social analysis could help map out the institutional landscape and some basic negotiating procedures that could make the state and its development projects accessible to villagers, but communities have their own patterns of inequality, conflict, and social exclusion. KDP always faced a tension between its principles of local decision-making and the fact that elite capture and rules that exclude women were always going to require some forms of outside intervention.

As KDP got larger, the schizophrenia that was already present in its early architecture returned to the forefront of problems. Was the goal of the program to increase the state's ability to deliver development services to villages, or was it to help villagers organize and engage with Indonesia's newly democratic state and its representative institutions? While the overarching law that embedded KDP into the budget kept the core principles intact, much of KDP's scale-up and appropriation by mainstream government ministries concentrated on restoring official's roles in the planning process, largely at the expense of KDP's bottom-up, more participatory and transparent approach. However, the battle continues to rage. KDP did not operate in isolation from the rest of Indonesia, and as Indonesian democracy continues to consolidate and popular expectations for responsive government continue to rise, there is pushback against the re-assertion of New Order-style bureaucratic control.

\section{Michael Cernea's Living Lessons}

KDP today, in its latest incarnation as the Indonesian Village Law, is the largest community development project in the world. It's scope crosses three time zones, from Aceh in the far northwest of Indonesia to Papua in the far east, adapting and adjusting to local social structures in a country known globally for its cultural, linguistic, and economic diversity. If the test of an applied development anthropology is whether it can produce projects that go beyond a single village, KDP has passed it. By 2018, the World Bank alone was financing over 190 large-scale community development projects in 79 developing countries. ${ }^{5}$

It is hard not to reflect on Michael's development contribution without noting here the extent to which the KDP story recapitulates the larger question of whether development should be a technocratic application of administrative and economic models for enabling a country's modernization, or whether it should be a more humanistic, values-driven enterprise that gives ordinary people more of a voice in

\footnotetext{
${ }^{5}$ Susan Wong and Scott Guggenheim, Community-Driven Development: Myths and Realities, Policy Research Paper 8435, Washington, DC; The World Bank, 2018.
} 
governance and development. KDP and its successors tried to do both, but the balancing act has not been without tensions.

Tania Li, in her often insightful and widely cited book, "The Will to Improve,", has critiqued KDP as a project that uses technocratic language to turn questions of political economy, local autonomy, and community culture into projects that reflect a development bureaucrat's vision of a better life. While I think Dr. Li misunderstands where the line between prescription and choice sits within KDP, she is right that project documents are written in the language of the World Bank, not in the language of the community. But this was Michael's genius. If anthropologists wanted to do more than provide critique after the fact, or stay confined to writing detailed community ethnographies and social assessments that would be read and set aside, they needed to learn the language and culture not just of the villages, but also of the agencies that had the resources and power. If KDP were to ever give villagers a fighting chance to build the roads or water sources that they actually wanted rather than what a government or a donor agency wanted them to do, then the puzzle of how to provide agency to villagers needed to be solved when somebody else held the money. That meant becoming fluent in two languages, not one. As Gloria Davis also somewhat facetiously advised me shortly before I left Washington for Indonesia, "if you can't write a contract for it, it isn't going to happen."

Much of Michael Cernea's message for development reflects a belief that it's not just incentives, but also institutions that matter. Sociology and anthropology offer a powerful set of empirical tools for uncovering how community and local institutions mediate and organize social action. Programs that work with and through local organizations will be more effective and more long-lasting than programs that just sweep them aside. KDP and the Indonesia community program became a laboratory for putting this idea to the test in a broad range of different areas: anti-corruption, social protection targeting, conflict recovery, and poor people's education, to name just a few examples. ${ }^{7}$

However, while much of Michael's early work was about how to get international development to open its doors to social science, by the time of KDP the most important questions were already what should social scientists be doing once they've been invited to walk through them. Because KDP was built around the tension between international and state development institutions on the one hand and

\footnotetext{
${ }^{6}$ Tania Li, The Will to Improve: Governmentality, Development, and the Practice of Politics, Durjam, North Carolina; Duke University Press, 2007, Governing Indonesia: convergence on the project system, Critical Policy Studies 10, 2015.

${ }^{7}$ Ben Olken, "Monitoring Corruption: Evidence from a Field Experiment in Indonesia" Journal of Political Economy 11(5): 200-249; V. Alatas, A. Banerjee, R. Hanna, B. Olken, and J. Tobias, "Targeting the Poor: Evidence from a Field Experiment in Indonesia", M. Woolcock, P. Barron, and R. Diprose, Contesting Development: Participatory Projects and Local Conflict Dynamics in Indonesia. New Haven, Yale University Press 2011; and M. Pradhan, D. Suryadarma, A. Beatty, M. Wong, A. Gaduh, A. Aliisjabana, and R. Artha, "Improving Educational Quality Through Enhancing Community Participation: Results from a Randomized Field Experiment in Indonesia." American Economic Journal 6(2): 105-126, 2014.
} 
community-owned planning on the other, the social team working on it had to move beyond design and come up with a long term program for sociological monitoring, evaluation, research, and adaptation as both government and community became more adept at using the program's rules to further their own interests. I still laugh when I recall how one subdistrict head in Aceh province got so frustrated by village women demanding that he account for KDP's reconstruction funds that he issued an official decree banning the public discussion of government budgets, a decree that he was quickly forced to revoke. But the point of the story is not that officials would try to undo KDPs transparency. That was entirely predictable. It was that there was something about KDPs transparency that was changing villagers' willingness to challenge traditional ways that local officials were exerting power. Had we stuck to monitoring disbursement and checking the government's compliance with key performance indicators from our home base in Jakarta, we never could have used the Aceh example to set up village-based women's monitoring groups across the entire program.

Michael was always too much the outsider trying to penetrate the technocracy to openly state how his political beliefs and his own personal history as an outsider permeated his approach to development. Nevertheless, they are present throughout his work. For all of the arguments about making development more efficient, ultimately the arguments for programs like KDP that try to empower poor communities are moral ones. Why was it important that women attend village planning meetings? Will that do the villages, or even the women, any good? Why should local governments bypass their own bureaucracies to provide funds to village community groups? What should the role of the bureaucracy be, if not to manage funds for the public good? Why do community groups need to be provided with facilitators to carry out tasks that could be performed by experienced, professional bureaucrats? Why do community groups build better, cheaper village infrastructure than government agencies?

In his seminal book, Development as Freedom, ${ }^{8}$ the economic philosopher Amartya Sen defined development as a quest for the freedom of individuals to live lives that are valued. Development, therefore, must include the freedom to choose among opportunities for realizing one's human potential. Sen argued that not only is the goal of development the achievement of this freedom, it is also the means by which it is achieved. Sen outlines five specific types of freedoms: political freedoms, economic facilities, social opportunities, transparency guarantees, and protective security. Political freedoms refer to the ability of the people to have a voice in government and to be able to scrutinize the authorities. Economic facilities concern both the resources within the market and the market mechanism itself. Income and wealth in the country should serve to increase the economic facilities for the people. Social opportunities deal with benefits like healthcare or education for the populace, allowing individuals to live better lives. Transparency guarantees allow individuals to interact with some degree of trust and knowledge of the interaction. Protective

\footnotetext{
${ }^{8}$ Amartya Sen, Development as Freedom, New York, Random House, 1999.
} 
security is the system of social safety nets that prevent a group affected by poverty being crushed and constrained by terrible misery.

Before Sen's work, these had been viewed as only the ends of development; luxuries afforded to countries that needed to focus on increasing income. Sen argues, however, that the increase in real freedoms should be both the ends and the means of development. While Sen strenuously defends the proposition that the development of these institutions will increase economic prosperity rather than being a burden upon it, he also insists that these represent significant goals in and of themselves, and not merely as a means to an end. In this context, political freedoms in particular have not just an instrumental and constructive role, but a constitutive role as well. Sen argues that "our conceptualization of economic needs depends crucially on open public debates and discussions, the guaranteeing of which requires insistence on basic political liberty and civil rights." Without such rights, the validity of a dominant political and economic agenda is not susceptible to alternative interpretation by those whose interests are at variance with those who control that agenda.

The large number of people who worked on KDP understood from the beginning that changing the way that Indonesia approached development was a small part of a much bigger social change. Indonesia's democratic transition is still being written, and even now we don't know for sure whether it will succeed or whether the authoritarian elitism of the past will return. Social analysis as advocated by Michael Cernea provided a way for development to engage people not just as individual beneficiaries, but as social and political beings whose institutions, priorities, values, and voice mattered. In today's world, when trust in government, in institutions, and in democracy itself are at record lows amidst the record high standards of wealth and consumption that unfettered markets had always promised, these lessons are not just historical relics to be studied in graduate classrooms, but guides for the development ideas of the future.

Scott Guggenheim is an anthropologist with a Ph.D. from Johns Hopkins University. After several years working on involuntary resettlement with Michael Cernea that included both policy work and operations in Colombia, Mexico, Somalia, India, Cote d'Ivoire, Cameroon and elsewhere, Mr. Guggenheim moved to Indonesia, where he became a global leader in community-driven development. He was team leader for the East Timor National Community Employment Project in 1999, the 2002 National Emergency Solidarity and Employment Project in Afghanistan, and was the World Bank's field coordinator for the 2004 Aceh tsunami recovery program. Between 2014 and 2018, Scott returned to Afghanistan, serving as senior development adviser to President Ashraf Ghani. Scott's publications include: Power and Protest in the Countryside (with Robert Weller); Anthropological Approaches to Involuntary Resettlement (w/Michael Cernea), The Search for Empowerment (with Michael Woolcock and Anthony Bebbington); and Community-Driven Development: Myths and Realities (with Susan Wong). Scott is currently an adjunct professor in Georgetown University's School of Foreign Service.

\footnotetext{
${ }^{9}$ https://en.wikipedia.org/wiki/Amartya_Sen
} 
Open Access This chapter is licensed under the terms of the Creative Commons Attribution 4.0 International License (http://creativecommons.org/licenses/by/4.0/), which permits use, sharing, adaptation, distribution and reproduction in any medium or format, as long as you give appropriate credit to the original author(s) and the source, provide a link to the Creative Commons license and indicate if changes were made.

The images or other third party material in this chapter are included in the chapter's Creative Commons license, unless indicated otherwise in a credit line to the material. If material is not included in the chapter's Creative Commons license and your intended use is not permitted by statutory regulation or exceeds the permitted use, you will need to obtain permission directly from the copyright holder. 